\title{
TCOM \\ Democratizing science in the eighteenth century: resonances between Condorcet's Sketch (1795) and twenty-first century science communication
}

\section{Lindy A. Orthia}

\section{Abstract}

Keywords

Introduction
The twenty-first century has witnessed a shift in science communication ideals from one-way science popularization activities towards more reflexive, participatory approaches to public engagement with science. Yet our longue durée histories of science communication's antecedents focus on the former and have neglected the latter. In this paper I identify parallels between modern science communication ideals and an iconic Enlightenment text, Condorcet's Sketch for a Historical Picture of the Progress of the Human Mind (1795). I show that Condorcet's carefully negotiated balance between scientific reason and radical principles of democracy has much in common with twenty-first century debates about science communication.

History of public communication of science; Participation and science governance; Science communication: theory and models

The longue durée history of science communication has been under-explored by researchers in our discipline. Chronologies of science communication commonly start in 1985, with the release of the Bodmer Report by the Royal Society of London, and only rarely discuss older events. Yet historians of science interested in science popularization have offered chronologies that go back two or three centuries in the West. A figure of about 200 years is commonly flagged, with many scholars identifying the early nineteenth century as science communication's origin point, particularly for Britain. For example, Holland and Miller [1997, p. 111] identify that period as "the "coming out" of science from the salon and drawing-room to the lecture theatre and popular presses'. Topham [2009b] discusses the emergence of the concept of 'popular science' in Britain and Germany at the turn of the nineteenth century, stating that terms like it 'have been used to organize scientific activity and discourse for barely two centuries' [Topham, 2009a, p. 313]. Pandora [2009] also identifies this period with popular science's emergence in the United States.

This chronology changes somewhat when discussing continental Europe. Several authors document late eighteenth century public activities in France that involved communicating science in broadly accessible ways, including public demonstrations, public lectures, open science courses, popular science books, and 
more [Bensaude-Vincent and Blondel, 2008, and references therein; Lynn, 2006]. ${ }^{1}$ Bensaude-Vincent goes still further, asserting that the late seventeenth/early eighteenth century Enlightenment figure Bernard Le Bovier de Fontenelle 'is considered to be the founder of science popularization' and the 'founding father of science communication' in France [Bensaude-Vincent, 2001, p. 102;

Bensaude-Vincent and Blondel, 2008, p. 8]. Mazzotti describes Fontenelle's approach as the 'domestication of philosophy', meaning 'the transfer of knowledge from the secluded space of its production to the civilized space of its public consumption [...] philosophical knowledge [...] reshaped in the forms of genteel conversation', which resonates broadly with conceptions of science communication in the late twentieth and twenty-first centuries [Mazzotti, 2004, pp. 131-132]. Fontenelle was not the only early eighteenth century figure engaged in this: Mazzotti's work discusses Venetian-born philosopher Francesco Algarotti, who popularized Newtonianism in continental Europe following Fontenelle's principles through his 1737 best-seller Newtonianism for Ladies, or Dialogues on Light and Colours. Definitions of 'science' and 'the public' have changed in the centuries since Fontenelle [Bensaude-Vincent, 2001; Bensaude-Vincent, 2009], but irrespective of this, science popularization activities (broadly defined) evidently took place throughout the eighteenth century in France and elsewhere.

The defining concepts these authors used for their periodizations included the blossoming of science activities in city streets, communication of the new philosophy in accessible language, the emergence of a 'public' separate from 'science' for whom science was popularized, and the existence of the phenomenon of 'popular science', or science of and by the people. Considerable scholarship debates the differences between these things, especially 'science popularization' versus 'popular science' [for examples see Bensaude-Vincent, 2009; Govoni, 2009; Topham, 2009a; Topham, 2009b]. But all are facets of what is increasingly called 'science communication' [Trench and Bucchi, 2015], and studying the origin point of all contributes to our picture of science communication history.

Govoni [2009, pp. 41-42] has suggested that further research into the history of science popularization will facilitate communication between historians of science, the general public, and scientists. It will also surely facilitate communication between historians and science communicators, to the benefit of both. In line with that end, one facet not discussed in the history of science popularization literature is histories of what we might today call 'public engagement with science'. The term 'public engagement' is used in diverse ways within science communication [Stocklmayer, 2013], but one prominent meaning advocates democratic empowerment for non-scientists within decision-making about science, often through dialogical and participatory approaches to communication, and with corresponding reflexivity on scientists' part. It is often contrasted with top-down, one-way or deficit model approaches to science communication that can maintain hierarchies of power between more powerful scientists and less powerful others [variations on such models are discussed by Irwin, 2008; Stocklmayer, 2013; Trench, 2008, see also the May 2016 issue of the journal Public Understanding of Science, especially the paper by Meyer].

\footnotetext{
${ }^{1}$ Historians debate the appropriateness of the word 'science' when referring to knowledge systems older than the early to mid nineteenth century and/or outside the West. I have chosen to use it here for simplicity's sake to refer to western knowledge about the natural world, but acknowledge the historiographic questions that are legitimately asked about it, and choose different wording where it becomes controversial.
} 
In this paper I offer an initial contribution to a history of reflexive and participatory approaches to the science and society relationship, with an examination of an iconic eighteenth century text. It is the final work of the French revolutionary, mathematician and philosophe Condorcet (1743-1794): his Sketch for a Historical Picture of the Progress of the Human Mind (Esquisse d'un tableau historique des progrès de l'esprit humain). First published posthumously in 1795, the Sketch has been described as 'perhaps the most influential formulation of the idea of progress ever written' [Baker, 2004, p. 56]. In it Condorcet articulated a vision of an ideal future society which valued scientific, empiricist 'reason' as the path to correct decision-making, but incorporated radically democratic mechanisms for enabling the nature of 'reason' to be determined anew in each generation. I argue that in this respect the Sketch shares a resemblance with twenty-first century ideals for public engagement with science. My aim is not to draw genealogical links between Condorcet's views and the present (though there may be some), but to offer some thoughts towards a longue durée history of ideas about public engagement with science by identifying parallels between Enlightenment philosophy and science communication today.

The Enlightenment and science communication
To fully understand the Sketch, we must consider what preceded it. Four decades earlier, in 1751, another singularly iconic Enlightenment work was published: the first volume of the Encyclopédie edited by Denis Diderot and Jean le Rond $\mathrm{d}$ 'Alembert. As a publication designed to capture and communicate all knowledge to people beyond the community of scholars, the Encyclopédie presents clear parallels with twentieth and twenty-first century science communication, particularly when we examine its editors' writings about the project. Diderot wrote that an encyclopedia's purpose was to 'collect knowledge disseminated around the globe' and to communicate it 'that our offspring, becoming better instructed, will at the same time become more virtuous and happy' [Diderot, 1755]. Within that body of universal knowledge, d'Alembert specifically championed 'the new philosophy' exemplified by Isaac Newton as representing the emergence of the light of truth, and he sought to promote it to the world [D'Alembert, 1751]. He also considered John Locke a hero of the new philosophy, because 'he reduced metaphysics to what it really ought to be: the experimental physics of the soul', by constructing knowledge out of his own lived sensations and experience, not merely trusting in the received knowledge in books [D'Alembert, 1751]. D'Alembert had reservations about communicating the principles of the new philosophy via accessible language, particularly the use of 'vulgar tongues' rather than Latin, concerned about the difficulty that would present to scholars across Europe trying to master their fields, who must also then master multiple languages. Nonetheless he conceded that 'this practice has contributed to making enlightenment more general' [D'Alembert, 1751], which he considered important, and which he and Diderot were evidently attempting to achieve through the Encyclopédie. In this regard d'Alembert praised Fontenelle, who he said 'has been able through the utmost method, precision, and clarity, to bring [abstract ideas] down within the compass of minds which one would have believed least capable of grasping them' [D'Alembert, 1751]. In all of this, eighteenth century versions of science communication ideals and practices are apparent.

Roche has argued that the texts these ideas were expressed in - Diderot's 1755 entry in the Encyclopédie for the term 'Encyclopédie' itself, and d'Alembert's 1751 
'Preliminary Discourse' to the Encyclopédie's first volume - 'may together be regarded as comprising a manifesto of the age of Enlightenment as a whole, produced by the editors of perhaps its most seminal work' [Roche, 2006, p. 189]. Core to the Enlightenment, then, was the desire to make knowledge generally available, particularly knowledge gained via observation of empirical experience, including what is now often considered to be early modern scientific knowledge, such as the work of Newton. The resonances with modern science communication are readily apparent in this core value.

This culture that believed in and aggressively promoted the new philosophy was the crucible in which Condorcet's ideas were initially forged. In his early writing he was so possessed by the vision of a society based on reason that he advocated a technocratic model of political governance, to ensure society was ruled correctly and without falling prey to 'prejudice' and 'superstition'. But by the time he finished the Sketch in 1794, he changed his mind.

As well as documenting the last phase of Condorcet's intellectual journey, the Sketch documents his transformation from technocrat to democrat. It was written as an outline for a never-completed longer work, but its values are clear. It presents a stylized history of humanity's eternal struggle for liberty in the face of tyranny, ending at the then-present time of the French Revolution. The final section is a vision of the future, which Condorcet imagined as a time:

when the sun shines only on free human beings who recognize no other master but their reason; when tyrants and slaves, priests and their benighted or hypocritical minions exist only in the history books and the theater, and our only concern with them is to pity their victims and their dupes, maintain a useful vigilance motivated by horror at their excesses, and know how to recognize and stifle, by the weight of reason, the first seeds of superstition and tyranny that ever dare to reappear. [Condorcet, 1795b, p. 69]

Condorcet's counterposition of 'reason' and 'freedom' against 'superstition' and 'tyranny' reveals the Sketch's key ideological commitment: that reason and freedom always and only go hand in hand, while superstition is both hallmark and tool of tyranny, used to oppress and control people in all societies [Condorcet, 1795a, p. 18].

The coupling of reason and freedom carries a technocratic flavor, and that interpretation of Condorcet's work has been in circulation since 1796, when philosopher Louis de Bonald condemned the Sketch for proclaiming 'a reign of reason that could only turn out to be domination in the name of science' [Baker's words; Baker, 2004, p. 57]. Rothschild notes that ever since Bonald, Condorcet has been seen 'as the embodiment of the cold, oppressive Enlightenment' [Rothschild, 1996, p. 677]. This is despite scholars also universally identifying Condorcet's interest in democracy. Broman [2012, p. 203] implies Condorcet held technocratic views, stating about his educational writings of 1791 (Écrits sur l'instruction publique) that he 'reserved to the scientific elite the promulgation of the basic truths of nature and society on which the progress of society depended'. Liedman [1994, p. 693] contends that Condorcet 'fancied a world government consisting of scientists', using as his evidence a fragment of writing inspired by Francis Bacon's New Atlantis. Baker argues the contrary, stating that even in this Fragment sur 
l'Atlantide, Condorcet differentiated between his dream of a society of scholars to inform public policy, and a government of the community at large whose aim is 'the maintenance of the equal rights of each of its members' [Condorcet, quoted by Baker, 1975, p. 341]. Williams [2004, pp. 113, 115] similarly interprets Condorcet's imagined 'Universal Republic of Sciences' as 'an alliance between government and science in which the free pursuit of knowledge and the free pursuit of happiness were envisaged as an integrated enterprise'. At the same time he states that in Condorcet's view 'only the rational, scientific management of change [...] would allow the mission of the Enlightenment to have a tangible, beneficial impact' [Williams, 2004, p. 2]. Other twenty-first century scholars [e.g. Beauchamp, 2009; Márkus, 2007] have continued to debate this point. Baker continues to offer a strong voice disputing the Bonaldian interpretation, arguing that Condorcet was not

offering a blueprint for scientific rule, as Bonald charged. His goal was not
social engineering carried out under the aegis of a technocratic state. [...]
Doubtless, there were tensions in his thinking, particularly in its early stages,
between the claims of scientism and the principles of democracy. [...] At times
under the Old Regime, when it seemed that the monarchy could be a vehicle
for enlightened political reform, he was willing to argue that the right to
participate in political decision making was secondary to the need for rational
decisions. But his views changed. [Baker, 2004, p. 62; see also Rothschild, 1996]

Irrespective of how one interprets Condorcet's earlier works, it seems apparent that the key tension for him was that between scientism and democracy. Once again, this parallels tensions in twenty-first century science communication that continue to debate whether scientific reason in public governance enhances liberty or oppression. For Condorcet, it was in writing his final work, the Sketch, that he found a new way forward for the relationship between scientific reason and the democratic imperative.

\section{The Sketch's model of reason and its application under a democracy}

The tension between reason and democracy in Condorcet's philosophy stemmed from the fact that, while he championed reason as the essential principle on which to found democracy, he also believed reason was a natural human ability, and that every person equally has the potential to access it. His valorization of reason may seem technocratic today, when we are likely to associate 'reason' with a scientific mode of thinking, but what Condorcet sought - at least at the end of his life when writing the Sketch — was the return of every human being's birthright to think for themselves. Reason for him, as for his mentor d'Alembert, was manifest in an empiricist, Lockean method for discerning truth, in which the sensation of experience was the ultimate source of knowledge. 'Without doubt', he wrote, 'it is only by meditation [on the lessons of experience], which furnishes us with fruitful combinations of ideas, that we can arrive at any general truths in the science of man' [Condorcet, 1795a, p. 11]. He believed that while human failings had obstructed reason historically, nonetheless the human mind's future progress was guaranteed, because the successes of the Lockean method had 'for ever imposed a barrier between mankind and the errors of its infancy' [p. 134].

Condorcet noted this Lockean method had been most comprehensively used 'to perfect the methods of the physical sciences', but that philosophers had also 
fruitfully applied it to every other arena of human endeavor, including moral science, politics and social economy [Condorcet, 1795a, pp. 133-134]. On the basis of this recent progress, he rejoiced that

At last man could proclaim aloud his right, which for so long had been ignored, to submit all opinions to his own reason and to use in the search for truth the only instrument for its recognition that he has been given. [p. 136]

He therefore saw reason as prior to any body of knowledge including the scientific, because knowledge was a product of the application of natural, unchained human reason. He believed that from this single truth - 'that man is a sentient being, capable of reasoning and of acquiring moral ideas' - the 'true rights of man' can be deduced [Condorcet, 1795a, p. 128, his emphasis].

Like d'Alembert, Condorcet identified 'great men' throughout history who contributed to human progress. But he also demonstrated his pleasure at the democratization of science and reason during the Enlightenment and French Revolution: 'Up to this stage, the sciences had been the birthright of very few; they were now becoming common property and the time was at hand when their elements, their principles, and their simpler methods would become truly popular' [Condorcet, 1795a, p. 164]. Going further than d'Alembert, he argued that communicating science in vernacular language was essential for achieving 'true equality in the use of reason and in the acquisition of necessary truths' [p. 118]. Echoing Diderot, he emphasized it was not enough that philosophers had become enlightened; the point was to spread enlightenment throughout society [pp. 169-170]. He objected strongly to a historical tendency in human societies to keep knowledge for an elite, condemning

the formation of a class of men who are the depositaries of the principles of the sciences or the procedures of the arts, of the mysteries or ceremonies of religion, of the practices of superstition, and often even of the secrets of legislation and politics. I refer to the separation of the human race into two parts; the one destined to teach, the other made to believe; the one jealously hiding what it boasts of knowing, the other receiving with respect whatever is condescendingly revealed to it; the one wishing to place itself above reason, the other humbly renouncing its own reason and abasing itself to less than human stature by acknowledging in others prerogatives that would place them above their common nature. [p. 17-18]

The tyrannical keepers of knowledge he was referring to included the late eighteenth century priesthood, but also avaricious scientists and technocrats, or anyone else who hoards knowledge. Condorcet believed the problem was universal among human societies, 'in all stages of civilization' [p. 18].

Condorcet defended the importance of making knowledge universally available, to effect and maintain human equality. He believed transforming society to equalize access to knowledge was the primary step in breaking humanity's chains. He praised Fontenelle and others for 'never ceasing to demand the independence of reason and the freedom of the press as the right and the salvation of mankind' [Condorcet, 1795a, p. 137]. Again this resonates with modern science 
communication, for which the most basic and least controversial principle is the importance of making knowledge accessible.

In the ninth chapter of the Sketch, which concerned Condorcet's review and critique of the most recent period of history including the French Revolution and the tyrannical forms of government it ostensibly opposed, he went still further, ultimately wanting to subordinate even reason to the ideal of democracy. It is here that we can find the most interesting parallels with twenty-first century principles for public engagement with science such as reflexivity and participatory democracy. Condorcet here articulated the political vision he believed had been finally discovered by humanity's long struggles, gradual progress and, ultimately, revolution. He believed that the will of the majority must stand as long as it does not breach the rights of the individual, and that no decision should stand forever because 'an obligation [...] ceases to be legitimate when, with a change in the individuals constituting the majority, the sanction of unanimity no longer exists' [Condorcet, 1795a, p. 128]. In other words, each generation had the right to make its own decisions about everything. He advocated the ability to change even a nation's founding constitution as 'the guarantee of every other right', because he believed that, as people become more enlightened, institutions need to change rather than 'remain for ever in their infancy' [p. 129]. In Rothschild's words, 'To change one's mind - to question the eternal truth of even one's own opinions - is itself, for Condorcet, of political importance', a sentiment echoed by Baker: 'It was therefore a crucial feature of Condorcet's thinking that scientific truths, always subject to correction, must never be propagated as dogmas' [Baker, 2004, pp. 62-63; Rothschild, 1996, p. 680]. The implication is that even these principles and ideals themselves must be subordinated to the will of the majority, if people are to have no master but their own reason. Condorcet wrote:

Doubtless there are issues on which the decision of the majority is likely to be in favour of error and against the interests of all: but it is still this majority that must decide which issues are not to be subjected to its own direct decision; it is the majority that must appoint those persons whose judgement it considers to be more reliable than its own; it is the majority that must lay down the procedure that it considers most likely to conduct them to the truth. [Condorcet, 1795a, pp. 128-129, my emphasis]

The majority should not just be empowered to make decisions; they must also be empowered to make decisions about how decisions should be made. More radically, Condorcet allowed the people to decide how and where truth is likely be found: to choose both their preferred reasoning 'procedure' and any experts they consider appropriate to the task. He prioritized democracy over his own conception of reason and in his imagined future world placed all power squarely in the hands of the citizenry, even if he thought their decisions were bad. In this sense, Condorcet's views in this last phase of his life had more in common with the twenty-first century public engagement ideals of participatory decision-making and scientific reflexivity than with more scientistic approaches to science communication that value scientific truth over all. 
Democracy to deficit in the Sketch?
There is a lacuna in the ointment of this characterization of the Sketch, because arguably Condorcet indirectly admitted the non-naturalness of reason, contrary to his stated beliefs about reason being inherent to every individual human being. An essential component of his future society, as outlined in his tenth and final chapter, was universal instruction in diverse areas of life, including:

This seems overly complex for the implementation of a natural ability, appearing rather to necessitate specialized training by experts. The passage betrays a sliver of Condorcet's past fears that the ignorance of the populace 'would remain a danger to liberty', in Baker's words [Baker, 1975, p. 269]. It also carries resonances with modern deficit model approaches to science communication. For example, there are similarities with some of the commitments of the Bodmer Report, which stated:

Greater familiarity with the nature and the findings of science will also help the individual to resist pseudo-scientific information. An uninformed public is very vulnerable to misleading ideas on, for example, diet or alternative medicine. An enhanced ability to sift the plausible from the implausible should be one of the benefits from better public understanding of science. [Royal Society of London, 1985, p. 10]

However, Condorcet's views differed somewhat from a stereotypical twentieth century deficit model perspective because he did not see science as a body of knowledge that people must learn in order to function rationally in the world. Rather, in his understanding, scientific reason was a strategy people could adopt to help them rediscover their own truth, as was their birthright. It was the process that mattered most, not the knowledge produced from it.

Further, Márkus [2007, p. 22] argues that, according to the Sketch, 'The fundamental turning points in history are revolutions in communication, that is, in the ways in which knowledge can be accumulated, distributed and transmitted' (his emphasis). Condorcet considered communication innovations important not as mere handmaidens in the service of science, but as the means through which people could get back to their natural cognitive processes and think for themselves, to strip away prejudicial thoughts that support despotism, and demand democratic transformation [Márkus, 2007, p. 28]. This emphasis on the revolutionary potential of changes in social relations facilitated by technological innovation, as opposed to an emphasis on the importance for liberty of learning scientific truths such as Newton's laws or Descartes' mathematical methods, also resonates with 
twenty-first century science communication ideals that advocate implementing new communication processes over disseminating particular scientific facts.

\section{Conclusions}

It seems clear that the debates and tensions within Condorcet's Sketch have much in common with twentieth and twenty-first century debates in science

communication. Given its eighteenth century creation, naturally the work does not fit neatly into any modern model of science communication; to assert such a fit would risk anachronistic argument. I am not aware of any direct genealogical links between the Sketch and modern science communication literature, so make no claims about the work's influence. Nonetheless elements of the text reveal that Condorcet strived to achieve a kind of ultimate position of reflexivity, in being willing to subordinate any technical or philosophical expertise - including his own - to the will of the majority. He also sought strategies to ensure the citizenry's active participation in decision-making, including decisions about the preferred model of reason itself, and including any decisions about which experts should advise the majority on a given issue. These ideals resonate with the more radical side of modern debates about science governance; on the other hand some of the $S k e t c h$ 's internal contradictions resonate with a less radical side [for example, see the counterposed positions on science governance of Collins and Evans, 2002; Jasanoff, 2003; Wynne, 2003]. Taken as a whole, perhaps the Sketch is best interpreted as engaging with some issues similar to those that modern science communication scholars are concerned with.

Such parallels provide food for thought about the possibility that there might be genealogical links yet to be traced between modern science communication and Enlightenment debates about appropriate configurations of reason and democracy. As noted, Bensaude-Vincent [2001] traces a history of science communication in France from Fontenelle to the present, suggesting there is a richer genealogical story to be told here. In the Anglophone tradition, more scientistically-minded commentators such as Holton [1992] have invoked the anti-superstition, pro-reason legacy of the Enlightenment in advocating the widespread public understanding of science, thus embodying a sort of genealogical link, but this remains outside of the reflexive/participatory 'public engagement' approach to science communication. The longue durée history of ideas about the place of participatory democracy and reflexivity within the science-society relationship remains under-explored in any tradition. It is my hope that the present study will provide a starting point for future research on this topic, that we can better understand the contexts in which the modern discipline of science communication came to be.

\section{References}

Baker, K. M. (1975). Condorcet: From Natural Philosophy to Social Mathematics. Chicago, U.S.A.: University of Chicago Press.

- (2004). 'On Condorcet's "Sketch"'. Daedalus 133 (3), pp. 56-64. URL: http://www . jstor.org/stable/20027930.

Beauchamp, G. (2009). 'Condorcet and the logic of technocracy'. Humanitas 22 (1-2), pp. 23-32.

Bensaude-Vincent, B. (2001). 'A genealogy of the increasing gap between science and the public'. Public Understanding of Science 10 (1), pp. 99-113. DOI: 10.1088/0963-6625/10/1/307. 
Bensaude-Vincent, B. (2009). 'A Historical Perspective on Science and Its "Others"'. Isis 100 (2), pp. 359-368. DOI: 10.1086/599547.

Bensaude-Vincent, B. and Blondel, C., eds. (2008). Science and Spectacle in the European Enlightenment. Aldershot, U.K.: Ashgate.

Broman, T. (2012). 'The Semblance of Transparency: Expertise as a Social Good and an Ideology in Enlightened Societies'. Osiris 27 (1), pp. 188-208. DOI: $10.1086 / 667827$.

Collins, H. M. and Evans, R. (2002). 'The Third Wave of Science Studies: Studies of Expertise and Experience'. Social Studies of Science 32 (2), pp. 235-296.

Condorcet (1795a). Sketch for a Historical Picture of the Progress of the Human Mind. English translation by J. Barraclough (1955). London: Weidenfeld and Nicolson.

- (1795b). Sketch for a Historical Picture of the Progress of the Human Mind: Tenth Epoch. English translation by K. M. Baker (2004), Daedalus 133 (3), pp. 65-82. URL: http://www. jstor .org/stable/20027931.

D'Alembert, J. (1751). ‘Preliminary Discourse'. English translation by R. N. Schwab and W. E. Rex (2009), Encyclopedia of Diderot \& d'Alembert - Collaborative Translation Project. Ann Arbor, U.S.A.: MPublishing, University of Michigan Library. URL: http://hdl. handle.net/2027/spo.did2222.0001.083.

Diderot, D. (1755). 'Encyclopedia'. English translation by P. Stewart (2002), Encyclopedia of Diderot $\mathcal{E}$ d'Alembert - Collaborative Translation Project. Ann Arbor, U.S.A.: MPublishing, University of Michigan Library. URL: http://hdl. handle.net/2027/spo.did2222.0000.004.

Govoni, P. (2009). 'The historiography of science popularization: Reflections inspired by the Italian case'. In: Popularizing Science and Technology in the European Periphery, 1800-2000. Ed. by F. Papanelopoulou, A. Nieto-Galan and E. Perdiguero. Farnham, U.K.: Ashgate, pp. 21-42.

Holland, S. and Miller, S. (1997). 'Science in the early Athenaeum: a mirror of crystallization'. Public Understanding of Science 6 (2), pp. 111-130. DOI: 10.1088/0963-6625/6/2/001.

Holton, G. (1992). 'How to think about the 'anti-science' phenomenon'. Public Understanding of Science 1 (1), pp. 103-128. DOI: 10.1088/0963-6625/1/1/012.

Irwin, A. (2008). 'Risk, science and public communication: Third-order thinking about scientific culture'. In: Handbook of Public Communication of Science and Technology. Ed. by M. Bucchi and B. V. Lewenstein. London \& New York: Routledge, pp. 199-212.

Jasanoff, S. (2003). 'Breaking the Waves in Science Studies: Comment on H.M. Collins and Robert Evans, 'The Third Wave of Science Studies". Social Studies of Science 33 (3), pp. 389-400. DOI: 10.1177/03063127030333004.

Liedman, S.-E. (1994). 'Condorcet and the postmodernists: Science, ethics, the arts and progress'. History of European Ideas 19 (4-6), pp. 691-697. DOI: 10.1016/0191-6599(94)90052-3.

Lynn, M. R. (2006). Popular science and public opinion in eighteenth-century France. Manchester, U.K.: Manchester University Press.

Márkus, G. (2007). 'Condorcet: Communication/Science/Democracy'. Critical Horizons 8 (1), pp. 18-32.

Mazzotti, M. (2004). 'Newton for ladies: gentility, gender and radical culture'. The British Journal for the History of Science 37 (2), pp. 119-146. DOI: 10.1017/S0007087404005400. 
Pandora, K. (2009). 'Popular Science in National and Transnational Perspective: Suggestions from the American Context'. Isis 100 (2), pp. 346-358. DOI: $10.1086 / 599548$.

Roche, D. (2006). 'Encyclopedias and the diffusion of knowledge'. In: The Cambridge History of Eighteenth-Century Political Thought. Ed. by M. Goldie and R. Wokler. Cambridge, U.K.: Cambridge University Press, pp. 172-194.

Rothschild, E. (1996). 'Condorcet and the Conflict of Values'. The Historical Journal 39 (3), pp. 677-701.

Royal Society of London (1985). The Public Understanding of Science: Report of a Working Party. London, U.K.: The Royal Society.

Stocklmayer, S. (2013). 'Engagement with science: Models of science communication'. In: Communication and Engagement with Science and Technology: Issues and Dilemmas: A Reader in Science Communication. Ed. by J. K. Gilbert and S. Stocklmayer. New York and London: Routledge, pp. 19-38.

Topham, J. R. (2009a). 'Introduction to Focus: Historicizing "popular science"'. Isis 100 (2), pp. 310-318. DOI: 10.1086/599551.

- (2009b). 'Rethinking the history of science popularization/popular science'. In: Popularizing Science and Technology in the European Periphery, 1800-2000. Ed. by F. Papanelopoulou, A. Nieto-Galan and E. Perdiguero. Farnham, U.K.: Ashgate, pp. 1-20.

Trench, B. (2008). 'Towards an Analytical Framework of Science Communication Models'. In: Communicating Science in Social Contexts. Ed. by D. Cheng, M. Claessens, T. Gascoigne, J. Metcalfe, B. Schiele and S. Shi. Springer, Netherlands, pp. 119-135. DOI: 10.1007/978-1-4020-8598-7_7.

Trench, B. and Bucchi, M. (2015). Science communication research over 50 years: patterns and trends. Ed. by J. L. M. B. Schiele and P. Baranger. Éditions Universitaires de Lorraine, France.

Williams, D. (2004). Condorcet and Modernity. Cambridge, U.K.: Cambridge University Press.

Wynne, B. (2003). 'Seasick on the Third Wave? Subverting the Hegemony of Propositionalism: Response to Collins \& Evans (2002)'. Social Studies of Science 33 (3), pp. 401-417. DOI: 10.1177/03063127030333005.

Lindy Orthia is a Senior Lecturer in science communication at the Australian National Centre for the Public Awareness of Science, the Australian National University. Her research interests are the longue duree history of science communication and relationships between fiction, science and the public. E-mail: lindy.orthia@anu.edu.au.

\section{How to cite}

Orthia, L.A. (2016). 'Democratizing science in the eighteenth century: resonances between Condorcet's Sketch (1795) and twenty-first century science communication'. JCOM 15 (04), A04. 